\title{
Comparison of The Female Stereotypes in $O$ Pioneers! by Willa Cather And Tenggelamnya Kapal Van Der Wijck by Hamka
}

\author{
Abbas \\ Universitas Hasanuddin Makassar, Sulawesi Selatan
}

\{Abbas.fsunhas@gmail.com\}

\begin{abstract}
This article compares the stereotypes of female in the main characters of two literary works, namely America and Indonesia in the early $20^{\text {th }}$ century. The main character is Alexandra in the novel $O$ Pioneers! by Willa Cather from America and Hayati in the novel Tenggelamnya Kapal Van Der Wijk by Hamka from Indonesia. The purpose of comparing the stereotypes of female fictional characters in these novels are to find out the ideology and values that people embrace in the fictional story. The writer uses a structuralism approach that emphasizes the intrinsic elements of literary works. Then, the writer in processing data utilizes feminist literary criticism and comparative literary studies to produce a comparative study of feminist perspective. The results of the analysis in this article show that there are similarities and differences in stereotypes between Alexandra and Hayati. The socio-cultural background adopted by the community is very influential in shaping the personality and mindset of Hayati, while Alexandra is very strongly influenced by the demands of the situation and conditions that develop around her.
\end{abstract}

Keywords: Stereotype, Female, Literary Works.

\section{INTRODUCTION}

The position of women in human civilization is one of the important discussions in the global world today. The facts and the impression that women are treated marginally or subordinately in human life make the issue of feminism attract the attention of researchers, academics, practitioners, and NGO activists to examine it. The issue raised in this thing is the idealization of equality and justice of gender relations between male and female. The formulation of gender equality and justice struggled by women is strongly influenced by the background values of religion and culture they hold. Indonesian women with a background in the religious values of Islam that they embrace are certainly different from American women with liberal ideals that they adhere to. This difference produces typical stereotypes between women of American and Indonesian.

One media that is able to describe the comparison of the stereotypes of women between nations is the literary works. Although literature is a product of an author's imagination, but it is strongly influenced by the author's experience in witnessing the living of women in the surrounding social life. One aspect of literary authors' criticism is the view and thinking of 
women reflected in fictional characters. The genius of the authors absorbs events in society and within a certain period of time, making literary works can be a documentation of human civilization, related to the issue of stereotyping of women.

An interesting literary work examined regarding to the comparison of stereotypes of women between nations is the novel O'Pioneers! and Tenggelamnya Kapal Van Der Wijck. Hamka expressed his imagination in the novel Tenggelamnya Kapal Van Der Wijck with the background of Minangkabau women, western Indonesia. On the other hand, O'Pioneers! was written by Willa Cather with the background of her imagination in the western United States around Nebraska. The two novels were written around the beginning of the twentieth century so the writer considered it worthy of the same issue at the same time. Based on the explanation stated, the writer interests in analyzing the stereotypes of the main female characters in literary works, namely Alexandra in the novel O'Pioneers! and Hayati in the novel Tenggelamnya Kapal Van Der Wijck.

The benefit can be obtained from this comparative analysis is the reader knows that the stereotypes of American and Indonesian women in literary works have differences and similarities. Geographical differences in literary works do not eliminate the relationship of universal issues in human life, including the stereotypes of women living in America and women who lived in Indonesia in the early twentieth century. Another benefit is readers can find out that women created by God have universal stereotypes in common. Even though they live in different backgrounds in beliefs, cultures, ideologies, perspectives, even geographical differences, they have values and norms in their capacity or nature as women. Finally, the reader can take the lesson that literary work is a documentation media for various issues in human life through the position, purpose of life, behavior, and the establishment of fictional characters.

\section{RESEARCH METHOD}

This article focuses on the analysis of the main female characters in literature so that the research method used is a structural approach. This approach is one of the methods of literary research that directs researchers to analyze the intrinsic elements of literary works, namely characterizations, plots, settings, themes, points of view, and others. Literary works are considered autonomous in the meaning that the stories and characters are considered a certain reality designed by the wishes of the author. The characters' views, thoughts, and actions are purely the results of the author's imagination. Some literary scholars regard the author's imagination as an imaginary reality in a fictional world. Aminuddin in Siswanto states that all acts and thoughts of fictional characters are a form of the author's wishes to be conveyed to the reader [1]. This statement indicates that the author has autonomous rights to move the fictional character in various forms such as criticism, violence, advice, provocation, rebellion, oppression, and others.

The issue discussed in this article is the stereotype of women in the main characters of literary works based on their views, thoughts, statements, and actions. Alexandra in novel O'Pioneers! is reflecting the public figure of a woman who is liberal and idealistic. Hayati in the novel Tenggelamnya Kapal Van Der Wijck characterizes a domestic female figure who is conservative and normative. Djajanegara considers the stereotype of women as an image of female characters in literary works [2]. The writer concludes that stereotyping is a certain labeling of the functions and roles of women in life, both in the public and domestic environment. Women's stereotypes can be a marker of the norms and values embraced by the community in which women live in a social environment. For example, the stereotype of 
Hayati shows the culture of Indonesian society in Minangkabau, but the stereotype of Alexandra indicates the lives of the American people in Nebraska.

The writer in portraying the stereotypes of the main characters in literature, Alexandra and Hayati refers to the masculine and feminine nature proposed by Pearson in scale item [3]. Femininity includes appreciative, considerate, contended, cooperative, dependent, emotional, excitable, fearful, feminine, fickle, forgiving, friendly, frivolous, helpful, jolly, modest, praising, sensitive, sentimental, sincere, submissive, sympathetic, talkative, timid, warm, and worrying. On the other hand, masculine character consists of aggressive, arrogant, assertive, autocratic, conceived, confident, cynical, deliberate, dominant, enterprising, forceful, foresighted, frank, handsome, hard-headed, industrious, ingenious, inventive, opportunistic, outspoken, self-confident, sharp-witted, shrewd, stern, strong, tough, and vindictive. The writer also adds the stereotype of Alexandra and Hayati based on an analysis of the views, thoughts, statements, and actions of the two fictional characters.

Regarding the analysis of female stereotypes in literary works, the writer uses the theory and method of feminist literary criticism. One of the main highlights in this criticism is describing the role and position of women in literary stories with their culture and views of life. In general, the stereotypes of women in social relations are grouped into two roles, namely domestic and public. Then, the stereotype of women in their position in society is grouped into two perspectives, namely conservative/ traditional and liberal/democratic. It is in line with Sugihastuti and Suhartono's view [4] that a feminist literary criticism views the character and awareness of female characters in literature related to culture, life, and situations that occur in the author and the people who influence it.

Application of feminist literary criticism in the study of the stereotypes of female characters from the novel O'Pioneers! by Willa Cather and the novel Tenggelamnya Kapal Van Der Wijck by Hamka, refers to the methodology proposed by Wiyatni [5]. The systematics of the writer's work in this study is based on feminist literary criticism, namely:

1. read and understand the story of novel O'Pioneers! by Willa Cather dan novel Tenggelamnya Kapal Van Der Wijck by Buya Hamka;

2. looking for the position, life goals, behavior, and attitude of the character of Alexandra in the novel O'Pioneers! dan Hayati dalam novel Tenggelamnya Kapal Van Der Wijck;

3. conduct literature studies from various writing sources related to the stereotypes of women in literary works;

4. collect and discuss Alexandra's stereotyped data in the novel O'Pioneers! and Hayati in the novel Tenggelamnya Kapal Van Der Wijck;

5. analyze the comparison of Alexandra's stereotypes in O'Pioneers! as a reflection of American women in Nebraska and Hayati in the novel Tenggelamnya Kapal Van Der Wijck as a reflection of Indonesian women in Minangkabau;

6. publish the results of the analysis into the form of articles in international conferences and indexed international journals.

Then, the writer describes the results of this analysis in the form of comparative literature. Women's stereotypes are compared based on geographical differences in the same time period. Stereotypes of American women in the novel O'Pioneers! compared to the stereotypes of Indonesian women in the novel Tenggelamnya Kapal Van Der Wijck in the same era at the beginning of the twentieth century. Endraswara explains that literary comparison can include literary relations according to place and time with cultural backgrounds [6] [7] [8]. 


\section{RESULT AND DISCUSSION}

Alexandra's facts, views, thoughts, statements, and actions as many as twenty-five stereotypes, the writer considers that Alexandra has stereotypes of femininity and masculinity also both. Alexandra's femininity stereotype is appreciative, considerate, cooperative, forgiving, friendly, helpful, jolly, sincere, submissive, and sympathetic. A number of feminine stereotypes is ten out of twenty-five stereotypes or 40 percent of her total stereotypes. On the other hand, she also has stereotypes of masculinity, namely aggressive, self-confident, dominant, forceful, foresighted, ingenious, outspoken, sharp-witted, shrewd, and tough. A number of masculine stereotypes is ten out of twenty-five stereotypes or 40 percent of her total stereotypes. The other stereotypes not mentioned by Pearson on the scale item, the writer categorizes bisexual item (femininity dan masculinity) on Alexandra's self are innovative, independent, objective, rational, and against tradition. The number of stereotypes is five out of twenty-five stereotypes or 20 percent of her total stereotypes.

The stereotype of American women in the fictional story O'Pioneer [9] reflected by Alexandra shows that she has a balance of characters, views, thoughts, statements, and actions based on typical femininity and masculinity. Alexandra has 40 percent typical femininity stereotypes and 40 percent typical masculinity and 20 percent typical bisexuals (femininity and masculinity). It indicates that Alexandra has the ability to take a role based on the situation at hand. When her situation requires her to play a feminine role, she appears as a typical woman. One day, she enjoyed the garden and farm-land with her three nephews, namely Milly, Sadie, and Stella, so she appeared as if a mother who loved her children temporarily. She also often works in the kitchen with her maids who are usually done by a traditional woman.

In different situations, Alexandra has the ability to take on the role of a male figure when the situation at hand needs to be dealt with typical masculinity. She managed to lead her family when her father, Mr. John Bergson died and made all of her younger brothers succeed in achieving their life. Oscar and Lou could be successful cultivators, Emil was able to become a prospective academic in college. Alexandra is also able to act decisively as befits a man. She was firm with her two brothers, Oscar and Lou, who sued the house and property so they could not face Alexandra. They resembled her like a female wolf who cannot be defeated.

The writer in the following table 1 identifies Alexandra's dominant stereotypes, which consists of femininity, masculinity, and bisexuality.

Table 1. Alexandra's dominant stereotypes in the fictional story in the novel O'Pioneer!

\begin{tabular}{lllc}
\hline \multicolumn{1}{c}{ Femininity } & \multicolumn{1}{c}{ Masculinity } & \multicolumn{1}{c}{ Bisexual } & Total \\
\hline appreciative & aggressive & innovative & 3 \\
Considerate & self-confident & independent & 3 \\
Cooperative & dominant & objective & 3 \\
Forgiving & forceful & rational & 3 \\
Friendly & foresighted & against tradition & 3 \\
Helpful & ingenious & & 2 \\
Jolly & outspoken & & 2 \\
Sincere & sharp-witted & & 2 \\
Submissive & shrewd & & 2 \\
Sympathetic & tough & $5(20 \%)$ & 2 \\
\hline \multicolumn{1}{c}{$10(40 \%)$} & \multicolumn{1}{c}{$10(40 \%)$} & $\mathbf{2 5}(\mathbf{1 0 0} \%)$ \\
\hline
\end{tabular}


On the other hand, Hayati's facts, views, thoughts, statements, and actions as many as twenty-five stereotypes. Hayati's femininity stereotype is appreciative, considerate, dependent, excitable, fearful, feminine, fickle, forgiving, friendly, helpful, jolly, modest, sensitive, sincere, submissive, sympathetic, timid, worrying. A number of feminine stereotypes is eighteen out of twenty-five stereotypes or 72.2 percent of her total stereotypes. On the other hand, she also has stereotypes of masculinity, namely assertive, deliberate, foresighted, frank, and tough. A number of masculine stereotypes is five out of twenty-five stereotypes or 20 percent of her total stereotypes. The other stereotypes not mentioned by Pearson on the scale item, the writer categorizes bisexual item (femininity dan masculinity) on Hayati's self are subjective and obedient to tradition. The number of stereotypes is two out of twenty-five stereotypes or 8 percent of her total stereotypes.

Hayati in the novel Tenggelamnya Kapal Van Der Wijck [10] has stereotypes as typical of Indonesian women in the fiction. She reflected herself as a figure dominated by feminine stereotypes. The dominance of the typical stereotype of femininity in Hayati is 72 percent, while the typical stereotype of masculinity in herself is only 20 percent. She has typical bisexual (femininity and masculinity) only 8 percent. It indicates that Hayati's ability to portray herself in life is dominated by typical stereotypes of femininity and few of her abilities act as typical masculine.

One fact shows that Hayati is dominated by a typical stereotype of femininity is her marriage to Azis which ended in her suffering and death. Hayati is unable to be independent in life, including decision making and activities. Her life always depends on the wishes of the family. She was helpless to maintain her love and hopes for marrying Zainuddin because she tied herself to the traditions and customs of the Minangkabau people. She was finally forced to marry Azis because of his family's wishes with the approval of Engku Datuk Garang as the customs leader, even though she actually loved Zainuddin. She did not dare to resist the traditions and customs that prevailed in the community. If she had the courage to resist tradition and be independent in determining her life choices, she would likely find happiness.

The writer identifies the dominant stereotype in Hayati which consists of femininity, masculinity and bisexuality as listed in the following table 2 .

Table 2. Hayati's dominant stereotypes in the novel Tenggelamnya Kapal van der Wijk

\begin{tabular}{lllc}
\hline \multicolumn{1}{c}{ Femininity } & \multicolumn{1}{c}{ Masculinity } & Bisexual & Total \\
\hline appreciative & assertive & subjective & 3 \\
considerate & deliberate & obedient to tradition & 3 \\
dependent & foresighted & & 2 \\
excitable & Frank & & 2 \\
Fearful & Tough & & 2 \\
feminine & & 1 \\
Fickle & & & 1 \\
Forgiving & & & 1 \\
friendly & & 1 \\
Helpful & & 1 \\
Jolly & & 1 \\
Modes & & 1 \\
sensitive & & 1 \\
Sincere & & 1 \\
submissive & & 1 \\
sympathetic & & 1
\end{tabular}


Timid

worrying

\begin{tabular}{llll}
$18(72.2 \%)$ & $5(20 \%)$ & $2(0.8 \%)$ & $\mathbf{2 5}(\mathbf{1 0 0} \%)$ \\
\hline
\end{tabular}

Based on the stereotypical description of the two fictional characters, readers can find a typical comparison between the two women at the beginning of the twentieth century, Alexandra as an American woman and Hayati as an Indonesian woman. Alexandra has a typical balance between stereotypes of femininity and masculinity, while typical Hayati is dominated by stereotypes of femininity and only a small amount of masculinity she has.

Table 3. The similarities and differences in stereotypes between typical Alexandra and Hayati

\begin{tabular}{|c|c|c|}
\hline \multirow{2}{*}{ Fictional Characters } & \multicolumn{2}{|c|}{ Comparison of Stereotypes } \\
\hline & Differences & Similarities \\
\hline Alexandra & $\begin{array}{l}\text { Cooperative } \\
\text { Aggressive } \\
\text { self-confident } \\
\text { dominant } \\
\text { Forceful } \\
\text { Ingenious } \\
\text { sharp-witted } \\
\text { Shrewd } \\
\text { innovative } \\
\text { dependent } \\
\text { Objective } \\
\text { rational } \\
\text { against tradition } \\
\text { dependent } \\
\text { excitable } \\
\text { Fearful } \\
\text { feminine } \\
\text { Fickle } \\
\text { Modest } \\
\text { sensitive } \\
\text { timid } \\
\text { worrying } \\
\text { assertive } \\
\text { deliberate } \\
\text { subjective } \\
\text { obedient to tradition }\end{array}$ & $\begin{array}{l}\text { appreciative, considerate, } \\
\text { forgiving, friendly, helpful, } \\
\text { jolly, sincere, submissive, } \\
\text { sympathetic, foresighted, frank, } \\
\text { tough }\end{array}$ \\
\hline Total & $26(67 \%)$ & $13(33 \%)$ \\
\hline
\end{tabular}

Comparisons between the stereotypes of Alexandra and Hayati have more differences than similarities. Their differences reached 26 or $67 \%$ of the total 39 stereotypes consisting of cooperative, aggressive, self-confident, dominant, forceful, ingenious, sharp-witted, shrewd, innovative, dependent, objective, rational, against tradition, dependent, excitable, fearful, feminine, fickle, modest, sensitive, timid, worrying, assertive, deliberate, subjective, and obedient to tradition. The similarity of their stereotypes is only 13 or $33 \%$ of the total 
stereotypes of 39 items. Their similarities include appreciative, considerate, forgiving, friendly, helpful, jolly, sincere, submissive, sympathetic, foresighted, frank, and tough.

The differences in the stereotypes of Alexandra and Hayati tend to be caused by differences in life background, action orientation, perspective, mindset, values, and ideology. Alexandra has a life background of challenges full that it requires hard work to survive, her actions are change-oriented, looking at life with confidence, thinking that is full of innovation, adopting hetereocultural values democratic and openness, believing in freedom and universal ideology. On the other hand, Hayati lives in a social environment that has been organized by tradition and customs, views life in fate and natural submission, acts oriented towards fate, natural thinking according to nature, adheres to conservative and closed monocultural values, believes in authoritarian ideology and domestication.

The stereotypical similarities owned by Alexandra and Hayati are only caused by both of them are naturally women who have feelings and beliefs that they will marry and have a family. They are both able to give appreciation, help and respect others sincerely. They also obey their respective beliefs about the future. Alexandra and Hayati have a common sense, which is forgiving, friendly, cheerful, sympathetic, and frank.

Alexandra and Hayati's fate are different because of the differences and similarities in stereotypes between them. Even though they have equally respective futures, but their final fate was different. Alexandra with her balance of femininity and masculinity, finally able to realize her dream. She became a successful, independent cultivator, and married someone she wanted named Carl Linstrum. The story of novel O'Pioneer! ended with a happy reunion meeting between Alexandra and Carl Linstrum and subsequently prepared themselves to marry and have a household. Alexandra continues to live with him by realizing their dream of cultivating fields and marrying her loved ones.

Different reality experienced by Hayati, she with the dominance of femininity in her failed to realize her hopes. She failed to marry a loved one named Zainuddin because she resigned to obeying the customary decision that wanted her to marry Azis. The novel story of Tenggelamnya Kapal Van Der Wijck ends with Hayati's divorce with Azis and then she is rejected by Zainuddin to live together to build a household. Hayati died along with failure to realize her hopes of living together with her loved ones.

The universal relationship of the differences and similarities in stereotypes between Alexandra, American woman and Hayati, Indonesian woman in the early twentieth century is women have hopes and imagination for the future, women aspire to live better and happier, women have a natural nature to marry and have a family. Alexandra hopes to succeed as a farmer and Hayati imagines that she can become a successful housewife. Alexandra aspires to live better in the future to cultivate the fields and Hayati aspires to have a household. Alexandra married the wife of Carl Linstrum and Hayati married to become Azis' wife.

\section{CONCLUSIONS}

The stereotype of American women in the fictional story of novel O'Pioneer! reflected by Alexandra shows that she has a typical balance of femininity and masculinity stereotypes. She is able to take a role based on the situation she is facing. When his situation requires her to play a feminine role, she appears as a typical woman. She also has the ability to take on the role of a male figure when the situation needs her to be dealt with typical masculinity. On the other hand, Hayati in the novel Tenggelamnya Kapal Van Der Wijck as a typical Indonesian woman is dominated by stereotypes of femininity. She portrays herself in life dominated by typical stereotypes of femininity and few of his abilities act as typical masculine. 
Alexandra and Hayati experience different fates because of their stereotypical differences and similarities. They have the aspirations of the future, but their final destiny is different. Alexandra with her femininity and masculinity balance, was finally able to realize her dreams. She became a successful, independent, and married with whom she wanted named Carl Linstrum. Unlike Hayati, she with the dominance of her femininity failed to realize her expectations. She failed to marry her beloved man named Zainuddin and married someone else, Azis. The universal relationship of stereotypical differences and similarities between Alexandra, American woman and Hayati, Indonesian woman in the early twentieth century were women with future expectations and imaginations, women aspired to live better and happier, women had a natural nature of marriage and family.

\section{REFERENCES}

[1] W. Siswanto, Pengantar Teori Sastra. Malang: Aditya Media Publishing, 2003.

[2] S. Djajanegara, Kritik Sastra Feminis: sebuah pengantar. Jakarta: Gamedia Pustaka Utama, 2000.

[3] J.C. Pearson, Gender and Communication. Iowa: Brown Publishers, 1985

[4] Sugihastuti and Suharto, Kritik Sastra Feminis: teori dan aplikasinya. Yogyakarta: Pustaka Pelajar, 2016.

[5] Wiyatni, Kritik Sastra Feminis: teori dan aplikasinya dalam Sastra Indonesia. Yogyakarta: Ombak, 2012.

[6] S. Endraswara, Metodologi Penelitian Sastra Bandingan. Jakarta: Bukupop, 2016.

[7] K. Saddhono, "Language of Coastal Communities in the Northern Coast of Central Java: Sociolinguistic Studies in Cultural Integration Maritime-Agrarian Perspective." Adv. Sci. Let. vol. 23 no. 10 pp 10054-10056, 2017

[8] K. Saddhono, "Integrating Culture in Indonesian Language Learning for Foreign Speakers at Indonesian Universities." J. of Lang. and Lit. vol. 6 no.2 pp. 349-353, 2015

[9] W. Cather, O'Pioneers!. New York: Signet Classics, 2012.

[10] Hamka, Tenggelamnya Kapal Van Der Wijck. Jakarta: Bulan Bintang, 2014. 